\title{
BIOSORPSI LOGAM BERAT TIMBAL (Pb) OLEH BAKTERI
}

\author{
Ummi Aminah ${ }^{1}$, Fatmawati Nur ${ }^{1 *}$ \\ Jurusan Biologi Fakultas Sains dan Teknologi \\ Universitas Islam Negeri (UIN) Alauddin Makassar \\ *email:fatenurkhalik@yahoo.com
}

\begin{abstract}
Abstrack: Contamination caused by heavy metals has a high potential of risk because they easily penetrate in to the trofic chain accumulating as organometallic compounds. Lead (II) has been as one of the most toxic heavy metals because it is associated with many health hazards. Therefore, people are increasingly interested in discovering new methods for effectively and economically scavenging lead (II). Recent studies demonstrate biosorption is a promising technology for the treatment of pollutant. Several research demonstrated the ability of lead biosorption by bacteria such as Enterobacter sp, Bacillus sp, Escherichia coli, Micrococcus sp, Aeromonas sp, Lactobacillus sp, and Pseudomonas sp.
\end{abstract}

Keywords: Bacteria, Biosorption, Lead

\section{PENDAHULUAN}

$\mathbf{P}$ encemaran lingkungan adalah suatu keadaan yang terjadi karena perubahan kondisi lingkungan yang meliputi tanah, air, dan udara. Kondisi ini tidak menguntungkan karena merusak dan merugikan kehidupan manusia, binatang dan tumbuhan. Hal ini disebabkan oleh kehadiran benda-benda asing seperti sampah, limbah industri, minyak, logam berbahaya sebagai akibat perbuatan manusia, sehingga mengakibatkan lingkungan tersebut tidak berfungsi seperti semula.

Pencemaran lingkungan hidup adalah masuk atau dimasukkannya makhluk hidup, zat, energi, dan/atau komponen lain ke dalam lingkungan hidup oleh kegiatan manusia sehingga melampaui baku mutu lingkungan hidup yang telah ditetapkan (UU RI No 32 Thn 2009 tentang Perlindungan dan Pengelolaan Lingkungan Hidup). 
Baku mutu lingkungan hidup adalah ukuran batas atau kadar makhluk hidup, zat, energi, atau komponen yang ada atau harus ada dan/atau unsur pencemar yang ditenggang keberadaannya dalam suatu sumber daya tertentu sebagai unsur lingkungan hidup (UU RI No 32 Thn 2009 tentang Perlindungan dan Pengelolaan Lingkungan Hidup).

Salah satu komponen pencemaran yang dapat terjadi di udara, darat, dan perairan adalah logam berat. Keberadaan logam berat disebabkan karena adanya penambangan, peningkatan penggunaan logam berat dalam berbagai industri, serta adanya limbah industri yang mengandung logam berat yang menjadi penyebab utama terjadinya keracunan dalam kehidupan masyarakat (Waluyo, 2009).

Seperti halnya sumber-sumber polusi lingkungan lainnya, logam berat tersebut dapat ditransfer dalam jangkauan yang sangat jauh di lingkungan, selanjutnya berpotensi mengganggu kehidupan biota lingkungan dan akhirnya berpengaruh terhadap kesehatan manusia walaupun dalam jangka waktu yang lama dan jauh dari sumber polusi utamanya (Darmono, 2006).

Masuknya bahan pencemar akan mampu menurunkan potensi sumber daya hayati. Pencemaran oleh bahan-bahan industri yang mengandung bahan berbahaya misalnya logam berat seperti Merkuri (Hg), Cadmium (Cd), Plumbum $(\mathrm{Pb})$ cenderung meningkatkan kasus keracunan dan gangguan kesehatan masyarakat. Logam berat merupakan salah satu bahan pencemaran yang sangat berbahaya bagi organisme karena dapat memberikan pengaruh letal dan sub letal. Pengaruh sub letal dapat berupa gangguan terhadap morfologi atau histologi, fisiologi (pertumbuhan, perkembangan, kemampuan berenergi, pernafasan, sirkulasi), biokimia (keadaan kimia darah, kegiatan enzim, dan endokrinologi), perilaku dan reproduksi (Darmono, 2006).

\section{Logam Berat Timbal (Pb)}

USEPA (U.S. Environmental Agency) mendata ada 13 elemen logam berat yang merupakan elemen utama polusi. Logam berat adalah unsur - unsur kimia dengan bobot jenis lebih besar dari $5 \mathrm{~g} / \mathrm{cm}^{3}$, terletak disudut kanan bawah sistem 
periodik, mempunyai afinitas yang tinggi terhadap unsur S. Sebagian besar logam berat seperti $\mathrm{Pb}, \mathrm{Cd}$, dan $\mathrm{Hg}$ merupakan zat pencemar yang sangat berbahaya (Connel, 1995).

Salah satu logam berat penyebab pencemaran adalah timbal atau timah hitam (Plumbum $=\mathrm{Pb}$ ). Timbal adalah logam yang mempunyai nomor atom 82 , berat atom 207.19 dan berat jenis 11.34, merupakan logam lunak yang berwarna coklat kehitaman. Pada tekanan udara 1 atmosfer, titik cairnya adalah pada suhu $327.5^{\circ} \mathrm{C}$ dan titik didihnya adalah pada suhu $174{ }^{\circ} \mathrm{C}$. Timbal merupakan salah satu logam berat yang sangat berbahaya bagi kesehatan manusia (Palar, 2008).

Konsentrasi timbal yang mencapai $188 \mathrm{mg} / \mathrm{l}$ dapat membunuh ikan-ikan di perairan. Menurut suatu data analisis penelitian, asupan harian melalui udara, air dan makanan jumlahnya masing-masing mencapai $15 \mathrm{mg}$ dan $140 \mathrm{mg}$. Berdasarkan data tersebut ternyata makanan merupakan sumber asupan utama timbal di dalam tubuh manusia. Makanan yang mengandung $100 \mathrm{mg}$ timbal menghasilkan timbal pada darah sebesar 60-180 ppb. Senyawa timbal yang masuk ke dalam tubuh melalui makanan akan ikut dalam metabolisme tubuh. Penyerapan timbal melalui saluran pencernaan berkisar antara 1-20\% dari total timbal yang berasal dari makanan dan minuman. Timbal dalam bentuk larutan akan diabsorbsi sekitar 1-10\% melalui dinding saluran pencernaan tertentu dan hanya dapat ditoleransi pada tingkat mikrogram (Darmono, 2006).

Timbal dan persenyawaannya banyak digunakan dalam berbagai bidang. Persenyawaannya dengan logam Bismut (PbBi) dengan perbandingan 93:7 digunakan sebagai grid dalam industri baterai. Timbal oksida $\left(\mathrm{PbO}_{4}\right)$ digunakan sebagai bahan aktif dalam mengalirkan arus elektron dalam industri baterai. Persenyawaan timbal dengan $1 \%$ stibium $(\mathrm{Sb})$ banyak digunakan sebagai bahan kabel telepon. Persenyawaan timbal dengan $0.15 \%$ As, $0.1 \%$ Sn dan $0.1 \% \mathrm{Bi}$, banyak digunakan sebagai kabel listrik. Persenyawaan timbal dengan atom nitrogen untuk membentuk senyawa azida banyak digunakan sebagai detonator (bahan peledak). Senyawa $\mathrm{PbCrO}_{4}$ digunakan dalam industri cat untuk mendapatkan warna kuning chrom, senyawa $\mathrm{Pb}(\mathrm{OH})_{2} .2 \mathrm{PbCO}_{3}$ untuk mendapatkan warna timbal putih sedangkan senyawa $\mathrm{Pb}_{3} \mathrm{O}_{4}$ untuk mendapatkan 
warna timbal merah. Senyawa silikat timbal ( $\mathrm{Pb}$-Silikat) digunakan sebagai bahan pengkilap keramik dan bahan tahan api. Persenyawaan antara timbal dengan arsenat dapat digunakan sebagai insektisida. Persenyawaan timbal dengan Te (Telurium) digunakan sebagai komponen aktif pada pembangkit listrik tenaga panas. Persenyawaan yang dibentuk dari logam timbal sebagai aditif yaitu $\left(\mathrm{CH}_{3}\right)_{4}$ $\mathrm{Pb}$ (tetrametil-timbal) dan $\left(\mathrm{C}_{2} \mathrm{H}_{5}\right)_{4}-\mathrm{Pb}$ (tetraetil-timbal) yang dicampurkan pada bahan bakar bensin untuk mengurangi letupan pada mesin kendaraan bermotor (Fardiaz, 1992).

Secara alamiah, timbal dapat masuk ke dalam perairan melalui pengkristalan timbal di udara dengan bantuan air hujan. Disamping itu proses korosifikasi dari batuan mineral akibat hempasan gelombang dan angin, juga merupakan salah satu jalur sumber timbal yang akan masuk ke dalam badan perairan (Palar, 2008).

Timbal yang ada dalam badan perairan dapat ditemukan dalam bentuk ionion divalen atau ion-ion tetravalen, ion timbal divalen digolongkan dalam kelompok ion logam kelas antara sedangkan ion timbal tetravalen digolongkan pada kelompok ion logam kelas B. Pengelompokan ion logam ini dibuat oleh Rhicardson. Bila didasarkan pada pengelompokan ion-ion logam Rhicard itu, ion timbal tetravalen mempunyai daya racun yang lebih tinggi bila dibandingkan dengan ion timbal divalen. akan tetapi dari beberapa penelitian menunjukkan bahwa ion timbal divalen lebih berbahaya daripada ion timbal tetravalent (Palar, 2008).

Senyawa timbal juga dapat ditemukan di dalam air minum bila air tersebut disimpan atau dialirkan melalui pipa yang merupakan alloy dari logam timbal. Kontaminasi air oleh logam timbal ini pernah melanda daratan Eropa beberapa tahun lalu. Hal ini disebabkan oleh pipa aliran air minum (pipa PDAM) yang dialirkan ke rumah-rumah mengandung logam timbal. Minuman keras seperti wiskey juga ditemukan mengandung logam timbal karena tutup dari minuman tersebut dari logam alloy, logam yang menjadi sumber kontaminasi minuman (Palar, 2008). 
Timbal bersifat toksik jika terhirup atau tertelan oleh manusia dan di dalam tubuh akan beredar mengikuti aliran darah, diserap kembali di dalam ginjal dan otak, dan disimpan di dalam tulang dan gigi. Penelitian menunjukkan bahwa timbal yang terserap oleh anak, walaupun dalam jumlah kecil, dapat menyebabkan gangguan pada fase awal pertumbuhan fisik dan mental yang kemudian berakibat pada fungsi kecerdasan dan kemampuan akademik (Palar, 2008).

Timbal yang terserap oleh ibu hamil akan berakibat pada kematian janin dan kelahiran prematur, berat lahir rendah bahkan keguguran. Sistem syaraf dan pencernaan anak masih dalam tahan perkembangan, sehingga lebih rentan terhadap timbal yang terserap. Anak dapat menyerap hingga 50\% timbal yang masuk ke dalam tubuh, sedangkan dewasa hanya menyerap 10-15\%. Anak dapat menyerap 3 kali dosis lebih besar dibandingkan orang dewasa karena memiliki perbandingan permukaan penyerapan dan volume yang lebih besar. Janin dapat menyerap timbal yang terkandung dan terakumulasi di dalam darah ibunya karena timbal dapat masuk ke dalam plasenta dengan mudah (Palar, 2008).

\section{Bakteri}

Nama bakteri berasal dari kata "bakterion" (bahasa Yunani) yang berarti tongkat atau batang dan bersel tunggal, berfilamen, dan bermisellium dari dunia Monera. Merupakan organisme yang paling sederhana dari semua organisme yang dikenal, serta demikian kecilnya sehingga hanya tampak dengan mikroskop. Pada umumnya tidak mempunyai klorofil, berkembangbiak dengan pembelahan diri, bentuk lain reproduksi aseksual, misalnya produksi spora yang disebarkan melalui udara atau kawanan berflagela (Pelczar, 2008; Subandi, 2009; Waluyo, 2004).

Berdasarkan bentuk morfologinya, maka bakteri dapat dibagi atas tiga golongan, yaitu golongan basil, golongan kokus, dan golongan spiral. Basil (dari Bacillus) berbentuk serupa tongkat pendek, silindris. Sebagian besar bakteri berupa basil. Basil dapat bergandeng-gandengan panjang, bergandengan dua-dua, atau terlepas satu sama lain. Yang bergandeng-gandengan panjang disebut streptobasil, yang dua-dua disebut diplobasil. Ujung-ujung basil yang terlepas satu sama lain itu mengumpul, sedang ujung-ujung yang masih bergandengan tajam. 
Kokus (dari Coccus) adalah bakteri yang bentuknya serupa bola-bola kecil. Golongan ini tidak sebanyak golongan basil. Kokus ada yang bergandenggandengan panjang serupa tali leher disebut streptokokus, ada yang bergandengan dua-dua, ini disebut diplokokus, ada yang mengelompok berempat, ini disebut tetrakokus. Kokus yang mengelompok merupakan suatu untaian disebut stafilokokus, sedang kokus yang mengelompok serupa kubus disebut sarsina. Spiral (dari Spirillum) adalah bakteri yang berbentuk lengkung yang pada pokoknya dapat dibagi menjadi bentuk koma (vibrio), jika lengkungannya kurang dari setengah lingkaran, dan bentuk spiral jika lengkungannya lebih dari setengah lingkaran, dan jika spiralnya halus dan lentur disebut spirochaeta, dan jika spiralnya tebal dan kaku disebut spirillum (Subandi, 2009) (Waluyo, 2004).

Bakteri tersebar luas di alam yaitu di tanah, di dalam endapan lumpur, di dalam endapan laut, di dalam air, di tempat-tempat tertentu seperti pada sumbersumber air panas, di dalam tubuh hewan, manusia, dan tanaman. Sebagian besar adalah saprotrof atau parasit dan sejumlah kecil adalah autotrof yang memperoleh energi dari proses oksidasi atau dari cahaya (karena adanya bakterioklorofil) (Waluyo, 2009; Purwoko, 2009).

\section{Biosorpsi Logam Berat Timbal oleh Bakteri}

Pencemaran lingkungan oleh logam berat dapat diatasi dengan cara bioremediasi. Bioremediasi didefinisikan sebagai penggunaan organisma hidup terutama mikroorganisme untuk mendegradasi pencemaran lingkungan yang merugikan ke tingkat atau bentuk yang lebih aman. Proses bioremediasi ini dapat dilakukan secara bioaugmentasi yaitu penambahan atau introduksi satu jenis atau lebih mikroorganisme baik yang alami maupun yang sudah mengalami perbaikan sifat (improved/genetically engineered strains) dan biostimulasi yaitu suatu proses yang dilakukan melalui penambahan zat gizi tertentu yang dibutuhkan oleh mikroorganisme atau menstimulasi kondisi lingkungan sedemikian rupa (misalnya pemberian aerasi) agar mikroorganisme dapat tumbuh dan beraktivitas lebih baik (Putra, 2005). 
Bakteri dapat dimanfaatkan dalam proses bioserbent atau pengikatan logam berat agar tidak membahayakan lingkungan. Pengikatan logam berat oleh bakteri dapat dipisahkan menjadi fase pengikatan dan transport aktif. Fase pengikatan tergantung pada metabolisme sel yaitu absorbsi melalui dinding sel atau permukaan eksternal, kemudian diikuti dengan transport aktif yang tergantung pada metabolisme sel. Pada proses metabolisme, logam berat dapat terakumulasi pada membran sel (ekstraseluler) dan pada sitoplasma (intraseluler) (Putra, 2005).

Akumulasi ekstraseluler dapat terjadi karena pengikatan ion-ion logam oleh polimer ekstraseluler atau polisakarida ekstraseluler yang dihasilkan sel-sel mikroorganisme dan komplikasi antara ion-ion logam yang bermuatan positif dengan sisi reaktif pada permukaan sel yang bermuatan negatif. Sedangkan akumulasi intraseluler dapat terjadi karena proses difusi yang tidak membutuhkan aktivitas mikroorganisme secara langsung dimana gen-gen yang mengendalikan plasmid dalam proses metabolisme tersebut (Purwoko, 2009). Cara lain adalah reverse osmosis, elektrodialisis, ultrafiltrasi dan resin penukar ion. Reverse osmosis adalah proses pemisahan logam berat oleh membran semipermeabel dengan menggunakan perbedaan tekanan luar dengan tekanan osmotik dari limbah. Kerugian sistem ini adalah biaya yang mahal sehingga sulit terjangkau oleh industri di Indonesia. Teknik elektrodialisis menggunakan membran ion selektif permeabel berdasarkan perbedaan potensial antara 2 elektroda yang menyebabkan perpindahan kation dan anion, juga menimbulkan kerugian yakni terbentuknya senyawa logam-hidroksi yang menutupi membran, sedangkan melalui ultrafiltrasi yaitu penyaringan dengan tekanan tinggi melalui membran berpori, juga merugikan karena menimbulkan banyak sludge (lumpur). Resin penukar ion berprinsip pada gaya elektrostatik di mana ion tersebut terdapat (Darmono, 2006).

Penelitian untuk mengetahui kandungan logam berat timbal $(\mathrm{Pb})$, jumlah koloni yang diisolasi, dan karakteristik bakteri di perairan pelabuhan Paotere Makassar telah dilakukan. Jenis penelitian ini adalah deskriptif yang menggambarkan tentang bakteri pengakumulasi logam berat timbal $(\mathrm{Pb})$. 
Pengambilan sampel dilakukan di pelabuhan Paotere pada 2 titik yaitu permukaan laut dan kedalaman $30 \mathrm{~cm}$. Hasil yang diperoleh memperlihatkan konsentrasi pencemaran logam berat timbal $(\mathrm{Pb})$ pada kedalaman $15 \mathrm{~cm}$ di 3 lokasi yaitu Pelabuhan Kapal Nelayan $=0.1270 \mathrm{ppm}$, Dermaga $=0.1103 \mathrm{ppm}$, dan $\pm 100 \mathrm{M}$ dari PT. IKI $=0.0849$ ppm. Karakteristik dari 9 isolat mempunyai bentuk yaitu circular = bulat, rhizoid = berbentuk seperti akar palsu, dan irregular $=$ tidak beraturan. Tepi yaitu entire $=$ rata, undulate $=$ bergelombang atau terdapat bentuk-bentuk seperti bergerigi, lobate $=$ bentuk seperti telinga, filamentous = terdapat bentuk-bentuk seperti benang halus, serta elevasi yaitu convex = cembung, umbonate $=$ meruncing/menonjol. Jumlah total bakteri pengakumulasi logam berat timbal $(\mathrm{Pb})$ di titik pengambilan sampel permukaan laut pada lokasi \pm $100 \mathrm{M}$ dari PT. IKI $=2.26 \times 10^{5} \mathrm{sel} / \mathrm{mL}$, di lokasi pelabuhan kapal nelayan $=1.51$ $\mathrm{x} 10^{5} \mathrm{sel} / \mathrm{mL}$, dan di lokasi dermaga $=1.45 \times 10^{6} \mathrm{sel} / \mathrm{mL}$. Untuk titik pengambilan sampel di kedalaman $30 \mathrm{~cm}$ pada lokasi dermaga $=4.91 \times 10^{6}$ sel $/ \mathrm{mL}$, di lokasi $\pm 100 \mathrm{M}$ dari PT. IKI $=1.98 \times 10^{4} \mathrm{sel} / \mathrm{mL}$, dan pada lokasi pelabuhan kapal nelayan $=1.63 \times 10^{5} \mathrm{sel} / \mathrm{mL}$ (Aminah, et. al., 2009).

Beberapa penelitian menunjukkan kemampuan bakteri dalam melakukan biosorpsi terhadap logam berat timbal diantaranya Enterobacter sp, Bacillus sp, Escherichia coli, Micrococcus sp, Aeromonas sp, Lactobacillus sp, dan Pseudomonas sp.

\section{Enterobacter sp}

Uji kemampuan Enterobacter dalam melakukan biosorpsi terhadap timbal dilakukan pada penelitian untuk mengetahui kemampuan biosorpsi kinetika dan kesetimbangan timbal $(\mathrm{Pb})$, tembaga $(\mathrm{Cu})$ dan kadmium $(\mathrm{Cd})$ dengan model Langmuir dan Freundlich. Penelitian ini menggunakan biomassa dari Enterobacter sp. J1 yang diisolasi dari tanaman air yang tumbuh pada limbah industri rumah tangga. Hasil menunjukkan bahwa Enterobacter sp. J1 mampu melakukan penyerapan $\mathrm{Pb}$ lebih dari $50 \mathrm{mg} / \mathrm{gram}$ sel kering, sementara memiliki keseimbangan kapasitas adsorpsi dari 32.5 dan $46.2 \mathrm{mg} / \mathrm{g}$ sel kering untuk $\mathrm{Cu}$ dan Cd. Secara umum, model Langmuir dan Freundlich mampu menggambarkan 
biosorpsi isoterm cukup baik. Model simulasi juga menunjukkan bahwa akumulasi intraseluler mungkin terjadi selama penyerapan $\mathrm{Pb}$ (Lu et.al., 2006).

Sebuah desain eksperimental baru menggabungkan mixture design dan Response Surface Methodology (RSM) dikembangkan untuk mengetahui perilaku adsorpsi kompetitif timbal, tembaga dan kadmium oleh bakteri Enterobacter sp. Dengan menggunakan dua desain percobaan yang berbeda, hasil menunjukkan bahwa preferensi logam penyerapan Enterobacter sp. J1 menurun dengan urutan $\mathrm{Pb}(2+)>\mathrm{Cu}(2+)>\mathrm{Cd}(2+)$. Kehadiran logam lainnya menghasilkan efek kompetitif. Pengaruh dari dua logam lain dalam sistem biosorpsi dapat dengan mudah ditentukan dengan membandingkan jarak menyimpang dari biosorpsi logam tunggal. Perilaku biosorpsi kompetitif dijelaskan dan diprediksi dengan menggunakan model Langmuir-Freundlich (Lu et. al., 2008).

Sebuah strain bakteri resisten timbal diisolasi dari limbah manufaktur perusahaan utama baterai di Goa, India telah diidentifikasi sebagai Enterobacter cloacae galur P2B berdasarkan morfologi, karakter biokimia, profil FAME dan rDNA data sekuens 16S. Strain bakteri ini dapat menahan timbal nitrat hingga 1.6 mM. Peningkatan yang signifikan dalam produksi eksopolisakarida (EPS) diamati karena produksi meningkat 28-108 mg/L berat kering bila terkena timbal nitrat 1.6 $\mathrm{mM}$. Hasil menunjukkan strain ini resistensi multidrug. Hasil ini secara signifikan berkontribusi pada pemahaman yang lebih baik tentang struktur, fungsi dan aplikasi lingkungan timbal dengan peningkatan EPS yang diproduksi oleh bakteri. Biopolimer ini dapat memainkan peran yang sangat penting dalam bioremediasi logam berat antara lain timbal (Naik et. al., 2012)

\section{Bacillus sp}

Bacillus gibsonii S-2 digunakan sebagai biosorben untuk menghilangkan ion logam timbal (II) pada air limbah dengan memperhatikan pengaruh $\mathrm{pH}$ dan suhu pada proses adsorpsi. Mekanisme biosorpsi timbal (II) dianalisis dengan FTIR dan EDX. Hasil penelitian menunjukkan bahwa nilai pH optimum untuk biosorpsi pada tiga temperatur yang berbeda, yaitu 20, 30 dan $40{ }^{\circ} \mathrm{C}$ adalah 4 . Mekanisme biosorpsi timbal (II) oleh biomassa B. gibsonii S-2 merupakan 
kombinasi pertukaran ion dan kompleksasi dengan kelompok fungsional yang ada pada permukaan biosorben. Biomassa $B$. gibsonii S-2 yang memperlihatkan kemampuan penyerapan yang tinggi terhadap timbal (II) dengan biaya yang lebih rendah dapat menjadi aplikasi potensial dalam pengolahan air limbah industri (Zhang et. al., 2013).

Penelitian tentang biosorpsi tembaga (II), timbal (II), besi (III) dan kobalt (II) oleh Bacillus sphaericus loaded Diaion SP-850 dan pemisahan prakonsentrasi logam-logam tersebut telah dilakukan. Parameter yang diukur adalah $\mathrm{pH}$, volume sampel B. sphaericus dan lain-lain. Penelitian juga memperhatikan efek dari alkali, ion alkali, dan beberapa ion logam pada retensi dari analit pada biosorben. Pemisahan dan prakonsentrasi dari $\mathrm{Cu}, \mathrm{Pb}, \mathrm{Fe}$ dan ion Co dari sampel dicapai secara kuantitatif. Batas deteksi dengan 3 sigma untuk ion analit berada di kisaran 0.20-0.75 L microg (-1) untuk sampel air dan dalam kisaran 2.5-9.4 ng g (-1) untuk sampel padat. Validasi prosedur dilakukan dengan mengguinakan certified standard reference materials (NRCC-SLRS 4 Riverine Water, SRM 2711 Montana soil and GBW 07605 Tea). Metode yang disajikan diaplikasikan pada penentuan ion analit dalam teh hijau, teh hitam, jamur yang dibudidayakan, gandum, nasi dan sampel tanah dengan hasil yang memuaskan (Tuzen et. al., 2007).

Adsorpsi timbal oleh pelet miselium Trametes gallica dan Bacillus cereus dengan co immobilisasi biomaterial mereka, diteliti dengan melihat pengaruh waktu kontak yang berbeda, nilai $\mathrm{pH}$ media, konsentrasi awal $\mathrm{Pb} 2^{+}$, konsentrasi bio-adsorben, dan membandingkan spektrum inframerah dari bio-adsorben sebelum dan sesudah penyerapan $\mathrm{Pb} 2{ }^{+}$. Efisiensi adsorpsi $\mathrm{Pb} 2{ }^{+}$oleh bio-adsorben yang tertinggi adalah konsentrasi bio-adsorben $2 \mathrm{gx} \mathrm{L} \mathrm{(-1),} \mathrm{pH}$ awal adalah 5.0, konsentrasi awal $\mathrm{Pb} 2{ }^{+}$adalah $50 \mathrm{mg}$ x L (-1), dan waktu kontak adalah 1 jam, dengan tingkat biosorpsi $\mathrm{Pb}^{+}$menjadi $71.7 \%$ untuk pelet miselium T. Gallica, 91.0\% untuk B. cereus, dan $96.9 \%$ untuk co immobilisasi biomaterial mereka. Spektrum inframerah dari bio-adsorben terutama terdiri dari zona penyerapan protein, karbohidrat, dan kelompok sulfur-fosfor menunjukkan bahwa kelompok 
hidroksil, karboksil, dan sulfur-fosfat memainkan peran penting dalam adsorpsi $\mathrm{Pb} 2^{+}$oleh bio-adsorben (Yang et. al., 2012).

Penelitian lain dilakukan untuk menguji kemampuan biosorbing terhadap logam oleh strain bakteri OSM29 yang diisolasi dari rizosfir tanaman kembang kol yang tumbuh di tanah irigasi terkontaminasi limbah industri. Analisis urutan gen berdasarkan16S rRNA, strain bakeri OSM29 diidentifikasi sebagai Bacillus thuringiensis. Berbagai konsentrasi (25-150 mgl (-1)) dari logam berat seperti kadmium, kromium, tembaga, timbal, dan nikel, B. thuringiensis strain OSM29 menunjukkan potensi yang jelas untuk mengurangi kadar logam tersebut. Pengaruh faktor fisiko-kimia tertentu seperti $\mathrm{pH}$, konsentrasi logam awal, dan waktu kontak pada biosorpsi diamati. PH optimum untuk pengurangan kadar nikel dan kromium adalah 7, sedangkan untuk kadmium, tembaga, dan timbal adalah 6 . Waktu kontak yang optimal adalah 30 menit untuk masing-masing logam pada 32 $\pm 2{ }^{\circ} \mathrm{C}$. Kapasitas regangan Biosorpsi OSM29 untuk ion logam tertinggi untuk Ni (94\%) yang diikuti oleh $\mathrm{Cu}(91.8 \%)$, sedangkan penyerapan terendah oleh biomassa bakteri tercatat untuk Cd (87\%) pada $25 \mathrm{mgl}(-1)$ konsentrasi ion logam awal. Koefisien regresi yang diperoleh untuk logam berat dari model Freundlich dan Langmuir adalah signifikan. Kelompok bahan kimia fungsional dari permukaan biomassa $B$. Thuringiensis yang diidentifikasi melalui Fourier transform infrared (FTIR) adalah amino, karboksil, hidroksil, dan gugus karbonil, yang mungkin terlibat dalam biosorpsi logam berat. Kemampuan biosorpsi $B$. thuringiensis strain OSM29 bervariasi tergantung $\mathrm{pH}$ dan konsentrasi logam. Biosorpsi masing-masing logam tersebut bisa diaplikasikan untuk perbaikan skala besar lokasi yang terkontaminasi (Oves et al., 2013).

\section{Escherichia coli}

Ekspresi metallothionein tikus pada E. coli (pMT-Thio) diteliti sebagai strategi untuk meningkatkan efisiensi biosorpsi logam dari bakteri biosorbents untuk $\mathrm{Pb}$ (II) dan (II) ion Cd. Hasil penelitian menunjukkan bahwa pMT-Thio secara significan menyebabkan peningkatan secara keseluruhan kapasitas biosorpsi, terutama untuk biosorpsi $\mathrm{Pb}$. Isoterm dan kinetik dari biosorpsi 
dievaluasi dalam sistem yang dirancang. Pengaruh konsentrasi logam dalam larutan dibahas melalui metode Langmuir dan Freundlich. Model Langmuir ditemukan berkorelasi baik dengan data eksperimen. Biomassa menunjukkan kapasitas maksimum sesuai dengan model adsorpsi Langmuir dari $28.14 \mathrm{mg}$ $\mathrm{Pb} / \mathrm{gp}$ MT-Thio dan $24.27 \mathrm{mg} \mathrm{Cd} / \mathrm{gp}$ MT-Thio. Penelitian ini membuktikan bahwa pMT-Thio merupakan bahan yang cocok untuk menghilangkan ion logam berat dari larutan berair, mencapai efisiensi removal yang lebih tinggi dari $90 \%$ untuk $\mathrm{Pb}$ (II) dan lebih tinggi dari 40\% untuk Cd (II), dan bisa dianggap sebagai bahan yang potensial untuk menangani pencemaran limbah oleh ion Cd (II) dan $\mathrm{Pb}$ (II) (Almaguer-Cantú et. al., 2011).

Metallothioneins (MTs) selalu dapat mengikat logam, kaya sistein, protein kecil yang terkenal dapat memberikan perlindungan terhadap logam berat beracun seperti kadmium. Dalam upaya untuk meningkatkan kemampuan sel bakteri untuk mengakumulasi logam berat, domba MTII diproduksi dalam fusi dengan Maltose Binding Protein (MBP) dan diterjemahkan ke kompartemen sitoplasma atau periplasmik Escherichia coli. Untuk semua logam yang diuji, tingkat yang lebih tinggi dari bioakumulasi diukur dengan strain over ekspresi MBP-MT dibandingkan dengan jenis kontrol. Sebuah bioakumulasi ditandai Cd, As, $\mathrm{Hg}$ dan Zn diamati pada galur over-ekspresi MBP-MT dalam sitoplasma, sedangkan $\mathrm{Cu}$ terakumulasi ke tingkat yang lebih tinggi ketika MBP-MT adalah over-ekspresi dalam periplasm. Sistem ekspor logam juga mungkin memainkan peran dalam bioakumulasi ini. Untuk menggambarkan hal ini, over-ekspresi MBP-MT dalam sitoplasma dari dua strain mutan E. coli terpengaruh dalam ekspor logam. Yang pertama, kekurangan dalam transporter ZntA dijelaskan untuk mengekspor berbagai ion logam divalen, menunjukkan meningkatnya kuantitas bioakumulasi Zn, Cd, Hg dan Pb. Strain kedua, LF20012, menunjukkan bioakumulasi arsenit. Strain over-ekspresi MBP-MT dalam sitoplasma, dalam kombinasi, dengan gangguan sistem ekspor logam, dapat digunakan untuk mengembangkan strategi untuk bioremediasi (Sauge-Merle et. al., 2012).

Penelitian lain dilakukan untuk menguji ekspresi metallothioneins mamalia dan ikan (MTs) pada Escherichia coli sebagai strategi untuk 
meningkatkan efisiensi biosorpsi logam dari bakteri biosorbents untuk timbal $(\mathrm{Pb})$, tembaga $(\mathrm{Cu})$, kadmium $(\mathrm{Cd})$, dan seng $(\mathrm{Zn})$. Selain itu, protein MT dinyatakan dalam kompartemen sitoplasma atau periplasma sel inang untuk mengeksplorasi efek lokalisasi pada logam biosorpsi. Hasil penelitian menunjukkan bahwa ekspresi MT menyebabkan peningkatan yang signifikan (5210\%) dalam efisiensi biosorpsi keseluruhan terutama untuk biosorpsi $\mathrm{Cd}$. Peningkatan MT-driven dalam biosorpsi logam lebih mengandalkan kenaikan tingkat biosorpsi ( $\mathrm{r}$ (2), properti kinetik) dari pada kapasitas keseimbangan biosorpsi (q (max), properti termodinamika), meskipun10-45\% dan 30-80\% peningkatan q ( $\max$ ) dari Cd dan Zn, masing-masing. Ekspresi MTs periplasma tampaknya lebih efektif dalam memfasilitasi kemampuan mengikat logam daripada ekspresi MT sitoplasma. Perbedaan dampak pada kemampuan biosorpsi diamati untuk asal protein MT, MT asal manusia (MT1A) adalah stimulator biosorpsi yang paling efektif dibandingkan dengan MTs yang berasal dari tikus (MT1) dan ikan (OmMT). Selain itu, efisiensi biosorpsi secara keseluruhan mengikuti urutan $\mathrm{Cd}>\mathrm{Cu}>\mathrm{Zn}>\mathrm{Pb}$ (Kao et. al., 2006).

\section{Micrococcus sp}

Efisiensi biosorpsi logam berat oleh bakteri yang diisolasi dari lumpur aktif diuji pada penelitian ini. Penelitian menunjukkan bahwa Pseudomonas pseudoalcaligenes dan Micrococcus luteus GC subgrup B memiliki kapasitas biosorpsi tinggi untuk $\mathrm{Cu}$ (II) dan ion $\mathrm{Pb}$ (II). Nilai $\mathrm{pH}$ adalah faktor paling penting pada biosorpsi ion logam. Kurva biosorpsi kinetik $\mathrm{Cu}$ (II) dan ion $\mathrm{Pb}$ (II) oleh sel menunjukkan dua proses: penyerapan yang cepat pada permukaan sel dan transformasi perlahan jangka panjang ke dalam sel. Ion $\mathrm{Cu}$ (II) dapat didesorbsi secara efektif dari sel Micrococcus luteus subkelompok GC B (Wang et. al., 2001).

Micrococcus luteus DE2008 memiliki kemampuan untuk menyerap timbal dan tembaga. Dampak dari logam pada biomassa dan viabilitas dari mikroorganisme serta penghapusan logam dari media kultur ini telah diteliti. Hasil penelitian menunjukkan mikroorganisme ini memiliki toleransi yang besar untuk 
timbal. Konsentrasi minimum logam (dinyatakan sebagai persentase sel hidup) adalah 0.5 mM untuk kedua logam. M. luteus DE2008 menunjukkan kapasitas penghapusan spesifik dari $408 \mathrm{mg} / \mathrm{g}$ untuk tembaga dan $1965 \mathrm{mg} / \mathrm{g}$ untuk timbal. Mikroorganisme ini memiliki kemampuan yang lebih untuk menyerap $\mathrm{Pb}$ (II) dari $\mathrm{Cu}$ (II). M. luteus DE2008 dapat dilihat sebagai mikroorganisme yang mampu memulihkan lingkungan tercemar oleh timbal dan tembaga (Puyen et. al., 2012).

\section{Aeromonas sp}

Biomassa Aeromonas hydrophila berhasil dimanfaatkan untuk menghilangkan timbal dari larutan berair. Pengaruh variabel seperti $\mathrm{pH}$, konsentrasi awal $\mathrm{Pb}$ (II), dosis biomassa, dan suhu pada pengambilan timbal diteliti. Hasil analisis regresi berganda dan analisis varians (ANOVA) menunjukkan bahwa konsentrasi memiliki hubungan yang positif, suhu dan dosis biomassa memiliki hubungan negatif, sedangkan $\mathrm{pH}$ memperlihatkan hubungan yang berbentuk kurva dengan penyerapan $\mathrm{Pb}$ (II). Penyerapan maksimum $\mathrm{Pb}$ (II) yang diprediksi oleh plot optimasi adalah $122.18 \mathrm{mg} / \mathrm{g}$ pada $20{ }^{\circ} \mathrm{C}$, konsentrasi awal $\mathrm{Pb}$ (II) $259 \mathrm{mg} / \mathrm{L}$, pH 5.0, suhu $20{ }^{\circ} \mathrm{C}$, dan dosis biomassa 1,0 g. Model Langmuir isoterm berlaku untuk data penyerapan dan kapasitas serap ditemukan $163.3 \mathrm{mg} / \mathrm{g}$ pada $30^{\circ} \mathrm{C}$, $\mathrm{pH} 5.0$, dan rentang konsentrasi $\mathrm{Pb}$ (II) 51,8-259 mg/L, menunjukkan bahwa biosorben lebih baik dibandingkan daripada biosorben yang dilaporkan dalam literatur (Hasan et. al., 2009).

Biomassa bebas dan amobil Aeromonas hydrophila telah digunakan untuk menghilangkan $\mathrm{Pb}$ (II) dari larutan berair. Kecocokan model Langmuir terhadap data penyerapan menunjukkan serapan monolayer dan kapasitas penyerapan biomassa adalah masing-masing 163.9 untuk biomassa bebas dan $138.88 \mathrm{mg} / \mathrm{g}$ untuk biomassa bergerak. Ditemukan $85.38 \%$ penghapusan $\mathrm{Pb}$ (II) dicapai pada bed height $19 \mathrm{~cm}$ dan laju alir $2 \mathrm{~mL} /$ menit dan model BDST sesuai dengan hasil eksperimen $(r(2)>0,997)$. Penelitian sorpsi-desorpsi menunjukkan bahwa biomassa polisulfon amobil dapat digunakan kembali hingga 16 kali siklus (Hasan et. al., 2010). 
Tributyltin Chloride (TBTC) dan bakteri muara tahan timbal dari muara Mandovi, Goa, India diisolasi dan diidentifikasi sebagai Aeromonas caviae galur KS-1 berdasarkan karakteristik biokimia dan analisis FAME. Bakteri ini mentolerir TBTC dan timbal hingga 1.0 dan 1.4 mM dalam Minimal Salt Medium (MSM) ditambah dengan glukosa $0.4 \%$. Scanning mikroskop elektron jelas memperlihatkan pola morfologi yang unik dari sel bakteri dalam bentuk rantai panjang saling terkait pada paparan 1 TBTC mM, sedangkan sel tetap tidak berubah pada $1.4 \mathrm{mM} \mathrm{Pb}(\mathrm{NO}(3))(2)$, tetapi biosorpsi timbal signifikan (8\%) pada permukaan isolat sel, jelas diperlihatkan oleh scanning mikroskop elektron digabungkan dengan energi X-ray spektroskopi dispersif. Analisis SDS-PAGE memperlihatkan isolat tahan timbal yang diinduksi protein dengan massa molekul 15.7, 16.9, dan $32.4 \mathrm{kDa}$ ketika sel-sel bakteri yang tumbuh di bawah tekanan dari $1.4 \mathrm{mM} \mathrm{Pb}(\mathrm{NO}(3))(2)$. Hal ini jelas menunjukkan kemungkinan keterlibatan bakteri tersebut secara eksklusif dalam menangani timbal. A. caviae galur KS-1 juga menunjukkan toleransi terhadap beberapa logam berat lainnya, yaitu: seng, kadmium, tembaga dan merkuri. Oleh karena itu, kita dapat menggunakan TBTC ini dan isolat bakteri tahan timbal untuk bioremediasi timbal dan juga untuk biomonitoring TBTC dari timbal dan lingkungan tercemar TBTC (Shamim et. al., 2013).

\section{Lactobacillus sp}

Bakteri asam laktat yang diisolasi dari berbagai makanan tradisional fermentasi Cina disaring untuk produksi exopolysaccharides (EPS). Strain 70810 dari Paocai Cina, yang diidentifikasi sebagai Lactobacillus plantarum (HQ259238) melalui bentuk morfologi, uji fisiologis, biokimia, dan 16S rDNA, dipilih karena kemampuan produksi tertinggi EPS $(0.859 \mathrm{~g} / \mathrm{L})$ untuk penelitian lebih lanjut. Biosorpsi $\mathrm{Pb}$ (II) dari larutan berair oleh 70810 EPS diteliti dengan parameter $\mathrm{pH}$ awal, waktu kontak, konsentrasi awal $\mathrm{Pb}$ (II), dosis adsorben, dan temperatur. Adsorpsi maksimum $\mathrm{Pb}$ (II) terjadi pada $\mathrm{pH} 5,30{ }^{\circ} \mathrm{C}$, dan 6 jam. Kapasitas adsorpsi juga ditemukan tergantung pada konsentrasi awal $\mathrm{Pb}$ (II) dan dosis adsorben. Adsorpsi permukaan terhadap logam pada permukaan 70810 EPS 
dikonfirmasi melalui scanning mikroskop elektron. Aplikasi praktis pada penelitian ini adalah Lactobacillus plantarum 70810 dapat digunakan sebagai kultur starter untuk produksi beberapa makanan fermentasi (misalnya, yoghurt atau susu kedelai fermentasi) dan produksi EPS yang dapat memenuhi permintaan konsumen untuk produk dengan tingkat aditif rendah. EPS dapat digunakan sebagai biosorben potensial untuk menghilangkan logam berat dari lingkungan fermentasi makanan ini mungkin memiliki efek potensial untuk mengeluarkan timbal dari tubuh manusia (Feng et. al., 2012).

Paparan diet untuk logam berat mungkin memiliki efek merugikan pada kesehatan manusia dan hewan, bahkan pada konsentrasi rendah. Bakteri probiotik tertentu mungkin memiliki sifat untuk mengikat racun dari makanan dan air. Penelitian ini menilai interaksi bakteri probiotik dengan kadmium dan timbal secara in vitro sebagai langkah pemeriksaan awal untuk mengidentifikasi strain yang dapat digunakan untuk dekontaminasi logam berat dalam makanan dan usus. Isoterm pengikatan untuk kadmium dan timbal ditandai untuk Lactobacillus rhamnosus LC-705, Propionibacterium freudenreichii subsp. shermanii JS dan campuran dari mereka digunakan dalam industri makanan. Perbedaan antara strain dan kombinasi mereka dalam kinerja mengikat pada kisaran konsentrasi antara 0.1 dan 100 mg.L-1 dievaluasi dengan model Langmuir untuk biosorpsi. Pengaruh $\mathrm{pH}$, waktu kontak, dan kelangsungan hidup pada kapasitas pengikatan juga diselidiki. Semua strain dan kombinasi antar strain dapat mengikat kadmium dan timbal secara efisien pada rentang konsentrasi rendah, umumnya diamati pada makanan. Namun, dua strain dan kombinasi strain berbeda secara signifikan. Pengikatan tampaknya terjadi seketika dan tergantung $\mathrm{pH}$, yang dapat dengan sempurna dijelaskan oleh model segmented linear-plateau (Ibrahim et. al., 2006).

Response Surface Methodology (RSM) berdasarkan pada central composite rotatable design digunakan untuk menyelidiki efek dari variabel operasi terutama $\mathrm{pH}$, bobot biomassa, dan konsentrasi awal ion timbal pada kapasitas adsorpsi timbal pada suhu kamar menggunakan sel Lactobacillus bulgaricus. Dengan menggunakan RSM, persamaan kuadrat polinomial diperoleh hasil untuk memprediksi persen dari penghapusan ion timbal. Analisis ragam 
menunjukkan bahwa pengaruh $\mathrm{pH}$ dan berat biomassa kering yang disimpulkan menjadi faktor kunci yang mempengaruhi kapasitas penghapusan ion timbal. Pada $\mathrm{pH}$ lebih rendah dari 2 (kondisi asam yang tinggi) dan dalam kondisi basa, tidak ada biosorpsi signifikan. Persentasi optimum penghapusan ion timbal ditemukan pada pH 6.78, konsentrasi biomassa 6.58 g/l dan konsentrasi awal timbal 36.22 ppm. Dalam kondisi ini, persen penghapusan ion timbal adalah $86.21 \%$. Penelitian ini menunjukkan efektivitas RSM untuk pemodelan proses biosorpsi (Sedighi et. al., 2012).

\section{Pseudomonas sp}

Biosorpsi logam berat dan uranium dari air limbah yang terkontaminasi dapat mewakili proses pemurnian yang inovatif. Studi ini mengkaji kemampuan penghapusan dari Pseudomonas putida dan bintang laut untuk timbal, kadmium, dan uranium, dengan mengukur kapasitas adsorpsi. Adsorpsi logam berat dan uranium oleh sampel dipengaruhi oleh $\mathrm{pH}$, dan meningkat dengan meningkatnya $\mathrm{Pb}, \mathrm{Cd}$, dan konsentrasi U. Semua logam berat teradsorpsi paling besar pada selsel mati daripada sel-sel hidup dan bintang laut. Kapasitas adsorpsi berturut-turut: $\mathrm{U}(\mathrm{VI})>\mathrm{Pb}>\mathrm{Cd}$. Hasil penelitian juga menunjukkan bahwa sel-sel membran bakteri dapat digunakan dalam pengobatan berkekuatan tinggi terhadap kontaminasi logam (Choi et. al., 2009).

Sebuah bakteri galur 4EA tahan timbal dari tanah yang terkontaminasi dengan limbah baterai dari Goa, India diisolasi dan diidentifikasi sebagai Pseudomonas aeruginosa. Isolat bakteri tahan timbal ini sangat menarik karena berhubungan dengan meningkatnya produksi siderophore timbal (pyochelin dan pyoverdine) hingga $0.5 \mathrm{mM}$ timbal nitrat sedangkan sel menunjukkan penurunan yang signifikan dalam produksi siderophore di atas $0.5 \mathrm{mM}$ timbal nitrat. Sel-sel bakteri juga mengungkapkan perubahan signifikan dalam morfologi sel sebagai pengurangan ukuran bila terkena timbal nitrat $0.8 \mathrm{mM}$. Peningkatan produksi siderophore yang jelas terdeteksi melalui Chrome Azurol S Agar Diffusion (CASAD) sebagai peningkatan diameter orange halo, dan pengurangan ukuran bakteri bersama dengan biosorpsi signifikan timbal tercatat dengan scanning 
mikroskop elektron digabungkan dengan energi dispersif X-ray spektrometri (SEM-EDX). Pseudomonas aeruginosa galur 4EA juga menunjukkan toleransi silang untuk logam beracun lainnya seperti kadmium, merkuri, dan seng selain resistensi terhadap antibiotik seperti ampisilin beberapa, eritromisin, amikasin, sefaleksin, kotrimoksasol, mecillinam, lincomycin, ciphaloridine, oleondamycin, dan asam nalidiksat (Naik et. al., 2011).

Sebuah isolat bakteri dari muara Mandovi Goa, India, yang resisten terhadap timbal nitrat $0.6 \mathrm{~mm}$ di medium Tris-buffered minimal diidentifikasi sebagai Pseudomonas aeruginosa strain WI-1. Amplifikasi PCR jelas mengungkapkan adanya metallothionein pengkodean gen bmtA bakteri yang bertanggung jawab untuk penyerapan logam. Analisis AAS membuktikan terdapat bioakumulasi intraseluler timbal $26.5 \mathrm{mg} / \mathrm{gram}$ berat kering sel. Analisis SDSPAGE dikonfirmasi bahwa bakteri timbal yang diinduksi metallothionein dengan berat molekul $11 \mathrm{kDa}$ dapat melakukan penghambatan pertumbuhan yang signifikan dari phytopathogenic jamur Fusarium oxysporum NCIM 1.008 oleh siderophore pada kultur kaya supernatan. Pot eksperimen dengan Pisum sativum L yang diinokulasi dengan strain ini memperlihatkan persentase perkecambahan benih yang tinggi dan pertumbuhan yang signifikan dibandingkan bibit tanpa inokulasi pada tanah yang diberi $7.704 \mathrm{~g} / \mathrm{kg}$ timbal, menunjukkan peningkatan pada toksisitas timbal. Strain tahan timbal ini menunjukkan toleransi untuk kadmium, merkuri dan Tributyltin Chloride (TBTC) dan resistensi terhadap beberapa antibiotik (Naik et. al., 2012).

\section{KESIMPULAN}

Pencemaran lingkungan yang disebabkan oleh logam berat memiliki potensi resiko yang tinggi karena mereka dengan mudah menembus ke dalam rantai makanan dan terakumulasi di dalam tubuh manusia. Timbal adalah salah satu logam berat yang paling berbahaya karena terkait dengan banyak bahaya kesehatan. Penelitian terbaru menunjukkan biosorpsi merupakan teknologi yang menjanjikan untuk mengatasi pencemaran logam ini. Beberapa bakteri yang menunjukkan kemampuan biosorpsi timbal diantaranya adalah Enterobacter $s p$, 
Bacillus sp, Escherichia coli, Micrococcus sp, Aeromonas sp, Lactobacillus sp, dan Pseudomonas sp.

\section{DAFTAR PUSTAKA}

Alloway BJ. Heavy Metals in Soils: Trace Metals and Metalloids in Soils and their Bioavailability. Environmental Pollution, Volume 22, 3rd Edition. Springer. Netherlands. 2013

Almaguer-Cantú V, Morales-Ramos LH, Balderas-Rentería I. Biosorption of lead (II) and cadmium (II) using Escherichia coli genetically engineered with mice metallothionein I. Water Sci Technol. 2011; 63(8):1607-13

Aminah U, Gosalam S, Nur F. Isolasi Bakteri Pengakumulasi Logam Berat Timbal $(\mathrm{Pb})$ di Perairan Pelabuhan Paotere Makassar. Skripsi. Jurusan Biologi Fakultas Sains dan Teknologi UIN Alauddin. Makassar. 2009.

Choi J, Lee JY, Yang JS. Biosorption of heavy metals and uranium by starfish and Pseudomonas putida. J Hazard Mater. 2009; 161(1):157-62

Connel DW. dan Miller GJ. Kimia dan Ekotoksikologi Pencemar. Penerjemah Yanti Koestoer dan Sahati. Universitas Indonesia Press. Jakarta. 1995.

Darmono. Lingkungan Hidup, Pencemaran dan Hubungannya dengan Senyawa Logam. Cet. I; Jakarta : UI Press. 2006

Fardiaz, Srikandi. Polusi Air dan Udara. Canisius. Yogyakarta: 1992.

Feng M, Chen X, Li C, Nurgul R, Dong M. Isolation and identification of an exopolysaccharide-producing lactic acid bacterium strain from Chinese Paocai and biosorption of $\mathrm{Pb}(\mathrm{II})$ by its exopolysaccharide. J Food Sci. 2012; 77(6):T111-7

Hasan $\mathrm{SH}$, Srivastava $\mathrm{P}$, Talat $\mathrm{M}$. Biosorption of $\mathrm{Pb}$ (II) from water using biomass of Aeromonas hydrophila: central composite design for optimization of process variables. J Hazard Mater. 2009; 15;168(2-3):1155-62.

Hasan SH, Srivastava P, Talat M. Biosorption of lead using immobilized Aeromonas hydrophila biomass in up flow column system: factorial design for process optimization. J Hazard Mater. 2010; 177(1-3):312-22

Ibrahim F, Halttunen T, Tahvonen R, Salminen S. Probiotic bacteria as potential detoxification tools: assessing their heavy metal binding isotherms. Can J Microbiol. 2006; 52(9):877-85 
Kao WC, Chiu YP, Chang CC, Chang JS. Localization effect on the metal biosorption capability of recombinant mammalian and fish metallothioneins in Escherichia coli. Biotechnol Prog. 2006; 22(5):125664

Lu WB, Shi JJ, Wang CH, Chang JS. Biosorption of lead, copper and cadmium by an indigenous isolate Enterobacter $s p$. J1 possessing high heavy-metal resistance. J Hazard Mater. 2006; 134(1-3):80-6

Lu WB, Kao WC, Shi JJ, Chang JS. Exploring multi-metal biosorption by indigenous metal-hyperresistant Enterobacter sp. J1 using experimental design methodologies. J Hazard Mater. 2008; 153(1-2):372-81

Naik MM, Dubey SK. Lead-enhanced siderophore production and alteration in cell morphology in a Pb-resistant Pseudomonas aeruginosa strain 4EA. Curr Microbiol. 2011; 62(2):409-14

Naik MM, Pandey A, Dubey SK. Pseudomonas aeruginosa strain WI-1 from Mandovi estuary possesses metallothionein to alleviate lead toxicity and promotes plant growth. Ecotoxicol Environ Saf. 2012; 79:129-33.

Naik MM, Pandey A, Dubey SK. Biological characterization of lead-enhanced exopolysaccharide produced by a lead resistant Enterobacter cloacae strain P2B. Biodegradation. 2012; 23(5):775-83

Oves M, Khan MS, Zaidi A. Biosorption of heavy metals by Bacillus thuringiensis strain OSM29 originating from industrial effluent contaminated north Indian soil. Saudi J Biol Sci. 2013; 20(2):121-9.

Palar, Heryando. Pencemaran dan Toksikologi Logam Berat. Cet. IV; Jakarta: Rineka Cipta, 2008

Pelczar MJ.Jr dan Chan ECS. Dasar-dasar Mikrobiologi. Jilid 1. Penerjemah Ratna Sri Hadioetomo, Teja Imas, S. Sutarmi Tjitrosomo, Sri Lestari Angka. UI Press. Jakarta. 2008.

Purwoko T. Fisiologi Mikroorganisme. Ed: 1. Cet: 2. Bumi Aksara. Jakarta. 2009.

Putra JA. Penanggulangan Pencemaran Logam Berat pada Perairan dengan Pendekatan Konsep Bioremoval. Karya Tulis Ilmiah. Universitas Lampung, 2005.

Puyen ZM, Villagrasa E, Maldonado J, Diestra E, Esteve I, Solé A. Biosorption of lead and copper by heavy-metal tolerant Micrococcus luteus DE2008. Bioresour Technol. 2012; 126:233-7

Sauge-Merle S, Lecomte-Pradines C, Carrier P, Cuiné S, Dubow M. Heavy metal accumulation by recombinant mammalian metallothionein within Escherichia coli protects against elevated metal exposure. Chemosphere. 2012; 88(8):918-24 
Sedighi M, Ghasemi M, Hassan SH, Daud WR, Ismail M, Abdallah E. Process optimization of batch biosorption of lead using Lactobacillius bulgaricus in an aqueous phase system using response surface methodology. World $\mathbf{J}$ Microbiol Biotechnol. 2012; 28(5):2047-55

Shamim K, Naik MM, Pandey A, Dubey SK. Isolation and identification of Aeromonas caviae strain KS-1 as TBTC- and lead-resistant estuarine bacteria. Environ Monit Assess. 2013; 185(6):5243-9.

Subandi M. Dasar-dasar Mikrobiologi. Gunung Djati Press. Bandung. 2009.

Tuzen M, Uluozlu OD, Usta C, Soylak M. Biosorption of copper (II), lead (II), iron (III) and cobalt (II) on Bacillus sphaericus-loaded Diaion SP-850 resin. Anal Chim Acta. 2007; 581(2):241-6

Undang-undang RI Nomor 32 Tahun 2009 tentang Perlindungan dan Pengelolaan Lingkungan Hidup. Kementerian Lingkungan Hidup Republim Indonesia. 2009.

Waluyo L. Mikrobiologi Umum. Universitas Muhammadiyah Malang Press. Malang. 2004.

Waluyo L. Mikrobiologi Lingkungan. Cet: 2. Universitas Muhammadiyah Malang Press. Malang. 2009.

Wang Y, Guo J, Liu R. Biosorption of heavy metals by bacteria isolated from activated sludge. Huan Jing Ke Xue. 2001; 22(6):72-5

Yang ZP, Chen P, Wang ZY, Hu R, Jing DJ, Huang QM. Lead adsorption by Trametes gallica, Bacillus cereus, and their co-immobilized biomaterial. Ying Yong Sheng Tai Xue Bao. 2012; 23(8):2212-8

Zhang B, Fan R, Bai Z, Wang S, Wang L, Shi J. Biosorption characteristics of Bacillus gibsonii S-2 waste biomass for removal of lead (II) from aqueous solution. Environ Sci Pollut Res Int. 2013; 20(3):1367-73 